\title{
Arenas de dragado marino como nueva fuente para materiales de construcción
}

\section{Dredged marine sand as a new source for construction materials}

\author{
$\underline{\text { J. Limeira }}^{(*)}$, L. Agulló(*), M. Etxeberria(*)
}

Recepción/Received: 6-VIII-10

Aceptación/Accepted: 12-IV-11

Publicado online/Online publishing: 1-VIII-11

\section{RESUMEN}

Este trabajo propone el uso de arenas de dragado marino (DMS) en pastas y morteros como material constructivo. Se utilizaron materiales de dos puertos españoles: DMS-0 del puerto de Sant Carles de la Ràpita, y DMS-A, DMS-B y DMS-C del puerto de Barcelona. El objetivo del estudio era evaluar el material DMS como adición (influencia sobre cohesión y fluidez) o como corrector granular (influencia sobre resistencia a la compresión) en diferentes mezclas de pasta y morteros de cemento, respectivamente. Se realizaron dos fases experimentales: primero, se empleó el DMS-0 en la producción de pastas y morteros (sustitución parcial de arena natural 0/2 mm); a continuación, se emplearon DMS-A, DMS-B y DMS-C en la producción de morteros (sustitución parcial de arena natural $0 / 5 \mathrm{~mm}$ ). Los resultados obtenidos fueron comparados con las mezclas de control y revelaron que la proporción óptima de sustitución de arenas naturales por DMS era del $25 \%$.

Palabras clave: arenas de dragado marino, morteros, propiedades mecánicas.

\begin{abstract}
This work deals with the use of dredged marine sand (DMS) in pastes and mortars as construction material. Different materials from two Spanish ports were used: DMS-O from Sant Carles de la Ràpita and DMS-A, DMS- $B$ and DMS-C from Barcelona. The aim of the study was to assess DMS as addition (its influence on cohesion and fluidity) or as a fine granular corrector (its influence on compressive strength) in different mixes of cement paste and mortars, respectively. Two experimental stages were carried out: firstly, DMS-0 material was used on the production of pastes and mortars (partial substitution of raw sand 0/2 mm); secondly, DMS- $A$, DMS- $B$ and DMS$C$ were used on mortar production (partial substitution of raw sand $0 / 5 \mathrm{~mm}$ ). The fresh and hardened properties obtained were compared to those of the control mixes; the results revealed $25 \%$ as an optimum substitution ratio of raw sands for DMS.
\end{abstract}

Keywords: dredged marine sand, mortars, mechanical properties.

(*) Universidad Politécnica de Cataluña (Barcelona, España). 


\section{INTRODUCCIÓN}

El crecimiento de la población y el desarrollo de infraestructuras en las zonas costeras han propiciado la construcción en terrenos ganados al mar. Como consecuencia de esto, también se observa un aumento en la utilización de áridos marinos como materiales constructivos para proyectos de hormigón y rellenos. Entre los proyectos de construcción en terrenos ganados al mar más significativos cabe destacar el aeropuerto de Hong Kong, las ampliaciones de la ciudad de Singapur, la tercera pista del aeropuerto de Sydney o los extensos proyectos de recuperación de tierra en Oriente Medio (1).

Desde los puntos de vista económico y medioambiental, el uso de material de dragado como nueva fuente de materiales de construcción ofrece considerables ventajas. Por ejemplo, podría solucionar la escasez de áridos así como las restricciones medioambientales relacionadas con la apertura de nuevas canteras, o la creciente demanda de áridos para la construcción civil. Además, cada vez son más necesarias las soluciones alternativas para la gestión de los sedimentos marinos después del dragado. Las nuevas directivas de la Unión Europea (2-7) con relación al desarrollo marino sostenible han animado a los gestores de puertos a reconsiderar las soluciones tradicionales como son la descarga sumergida de subproductos en vertederos o vertidos al mar.

No se conoce públicamente el volumen total anual de las actividades de dragado en los puertos españoles. Sin embargo, las importantes obras de ampliación de algunos puertos revelan la cantidad de descarga de sedimento marino producida durante el mantenimiento y las actividades de dragado, como por ejemplo la cuarta ampliación del puerto de Barcelona por medio de la desviación de la desembocadura del río Llobregat $2 \mathrm{~km}$ hacia el sur, doblando así la extensión de la zona portuaria actual. El plan de ampliación prevé que en 2050 la zona alcanzará las 1.265 hectáreas. Las obras de ampliación representaron más de 4 millones de metros cúbicos de dragado. Otro ejemplo son las obras para ganar terreno al mar en el puerto de Gijón, que suponen aproximadamente unos 20 millones de metros cúbicos de dragado de arena (8).

Según Chapman (9), en Gran Bretaña la arena y la grava marinas con fines constructivos se usaron en sus costas por primera vez probablemente a mediados del siglo XIX. Se realizaron varios estudios (9-12) sustentados en debates con las partes interesadas y se pudieron obtener datos técnicos fiables. Las dos diferencias principales entre estos materiales y los áridos naturales residen en la presencia y el tipo de las impurezas (10). Es de esperar que los áridos marinos contengan sal y conchas. No obstante, el contenido de sal se verá alterado por el proceso

\section{INTRODUCTION}

Population growth and infrastructure development in coastal areas have led to a rise in land reclamation. Consequently, there is also an increase in the use of marine aggregate used as construction material for concrete and filling projects. As the world's major land creation projects it is worth highlighting the airport of Hong Kong, the city extensions in Singapore, Sydney's third runway or the vast reclamation projects in the Middle East (1).

From the economic and environmental point of view, the use of dredged material as a new source for construction materials offers considerable advantages. For instance, it could solve the shortage of aggregates as well as environmental constraints concerning the opening of new quarries or the continuously increasing demand for aggregates in civil construction. Moreover, alternative solutions to the management of marine sediments after dredging are increasingly required. The new European Union directives (2-7) with regard to sustainable marine development have encouraged harbor managers to reconsider traditional solutions such as immersion disposal in landfills of by-products or dumping at sea.

The total annual volume of dredging activities in Spanish ports is not publicly known. However, some important harbor expansion works are revealing the amount of marine sediment disposal during maintenance and capital dredging activities, such as the fourth enlargement of the Port of Barcelona by diverting the mouth of the Llobregat River $2 \mathrm{~km}$ to the South, doubling the present port area in size. The extension plan foresees that in 2050 the area will reach 1265 hectares. The expansion works represented more than 4 million cubic meters of dredging. Another example is the reclamation works of the Port of Gijón, which involves approximately 20 million cubic meters of sand dredging (8).

According to Chapman (9), in Great Britain, marine sand and gravel for building purposes were probably first used throughout their coasts approximately in the middle of the nineteenth century. Several studies (9-12) were carried out supported by discussion from interested parties and reliable technical data was obtained. The two main differences between these materials and raw aggregates lie on the presence and type of impurities (10). Marine aggregates are expected to include salt and shell content. Nevertheless, salt content will be altered 
de dragado o almacenamiento. Por lo tanto, en lo que se refiere al contenido de sal en los áridos marinos, se debe tener en cuenta que tras el dragado el material está totalmente saturado, con un contenido de sal directamente proporcional al contenido de humedad. Según Roeder (10), la arena no lavada con un contenido típico de humedad del $10 \%$ contendrá un $0,3 \% \mathrm{NaCl}$ ( $3 \%$ de $10 \%$ ). Estos contenidos de sal deben ser considerados como niveles máximos que disminuirán en mayor o menor medida dependiendo del grado de lavado o drenaje realizado. Si no se adopta procedimiento alguno de lavado, lo más probable es que la pérdida de agua debida a la evaporación en las zonas de acopio tenga como resultado el aumento de la proporción sal/agua. Sin embargo, la cantidad de conchas presentes sólo se verá afectada marginalmente. La naturaleza petrológica de los áridos marinos varía según la ubicación de la fuente, como también ocurre con los materiales de origen terrestre. Normalmente existe una gran similitud entre la fuente marina y la de su entorno terrestre.

Según Newman (11), la presencia de partículas de material de conchas así como de gasterópodos es lo que diferencia a los áridos de dragado marino de los áridos de origen terrestre. Aunque las partículas de concha se rompen con facilidad, el componente de carbonato de calcio es denso (gravedad específica: 2,7 ) y tiene una baja porosidad (absorción de agua: 1,3\%). Las partículas de concha son básicamente resistentes y duraderas. Además, su característica más importante es su forma física, ya que la forma muy escamosa de la partícula produce un material con una granulación más gruesa y un índice de poros más elevado.

A pesar de que se han estudiado diferentes aplicaciones de la arena de dragado marino (DMS) (13-16), se podría considerar que su principal aplicación es la de mejora de pavimentos, puesto que su distribución granulométrica conduce a una mejor compactación. Además, en el caso de hormigón no reforzado o en masa, la presencia de sal y conchas no conlleva problemas en lo que respecta a la durabilidad o la necesidad de procesos de lavado o descontaminación (12). Los estudios presentados por Newman (11) concluyeron que es poco probable que la presencia del ión de cloruro del agua salada afecte las propiedades del hormigón más allá de una leve aceleración de los tiempos de fraguado y la tasa de aumento de resistencia. Otros trabajos (17-22) señalaban la viabilidad de usar sedimentos de dragado marino en las bases y subbases de construcciones de pavimentos portuarios. Se incorporaron en los sedimentos marinos mezclas de aglomerantes hidráulicos (cemento o cal) para mejorar su distribución granulométrica y corregir su esqueleto granular.

El análisis de su impacto mecánico y medioambiental (lixiviación, concentración de contaminantes) reveló que by the dredging process or storage. Therefore, as regards salt content in marine aggregates, it must be considered that after dredged, the material is fully saturated, with a salt content directly proportional to the moisture content. According to Roeder (10), unwashed sand with a typical $10 \%$ moisture content will contain about $0.3 \% \mathrm{NaCl}$ ( $3 \%$ of $10 \%$ ). These salt contents must be considered as maxima which will be reduced to a greater or lesser extent depending on the degree of eventual washing or drainage carried out. If no washing procedure is adopted, the loss of water due to evaporation on stockpiles is likely to have the effect of increasing the salt/water ratio. The amount of existing shells will be marginally affected. The petrological nature of marine aggregates varies according to the location of the source, as it also occurs with land-based materials. Usually, a close similarity is found between the sea source and that of its inland neighbor.

According to Newman (11), it is the presence of flaky particles of broken shell material, as well as unbroken gastropods, which differentiates dredged marine aggregates from land-based aggregates. Although shell particles are easily broken, the calcium carbonate component material is dense (specific gravity: 2.7) and has a low porosity (water absorption: 1.3\%). Shell particles are basically strong and durable. Moreover, their most important characteristic is their physical form, since the very flaky particle shape produces a more coarsely graded material with a higher void ratio.

Even though different applications of dredged marine sand (DMS) have been studied (13-16), pavement enhancement could be considered its main application, since its grading distribution leads to better compaction. Also, for unreinforced or mass concrete, the presence of salt and shell does not imply further problems regarding durability or the need for washing or decontaminating processes (12). Studies presented by Newman (11) concluded that the presence of chloride ion from the salt water is unlikely to affect the properties of concrete beyond a mild acceleration of the setting times and rate of strength gain. Other works (17-22) indicated the feasibility of using dredged marine sediments in the bases and sub-bases of harbor pavement constructions. Hydraulic binder mixes (cement or lime) have been incorporated into DMS in order to improve its grading distribution and correct the granular skeleton.

The analysis of its mechanical and environmental impact (leaching, contaminant concentration) revealed that the 
el material estudiado arroja unas propiedades finales compatibles con los requerimientos de diseño habituales. El tratamiento con base cemento $(23,24)$ es una técnica muy conocida aplicada al tratamiento de sedimentos dragados. Su principal objetivo es mejorar el empaquetamiento y las propiedades a compresión exigidas para aplicaciones geotécnicas. En el caso de material contaminado, se suelen utilizar varias técnicas de descontaminación (25), como la estabilización de metales pesados y la eliminación térmica de materia orgánica.

Se ha desarrollado una experiencia piloto a escala industrial con DMS como material de construcción para la ejecución de tres secciones de pavimentos portuarios de hormigón, descrita en Limeira et al (26). Dicho trabajo evalúa el DMS usado como corrector granular de finos con una sustitución del $18 \%$ de la arena natural $0 / 2 \mathrm{~mm}$ (en peso) en la dosificación de hormigón.

En este trabajo de investigación se utilizaron los materiales DMS obtenidos en dos puertos españoles diferentes (DMS-0 del puerto de Sant Carles de la Ràpita y DMS-A, DMS-B y DMS-C del puerto de Barcelona) como material componente para la producción de pastas y morteros; el DMS se empleó como adición por peso del cemento y en sustitución parcial de la arena natural con diferente granulometría para validar su influencia sobre esos materiales cementicios. Se determinaron y evaluaron las características químicas, físicas y mecánicas de todos los materiales de DMS para comprobar las exigencias de los áridos para la producción de materiales cementicios.

La fase experimental de los materiales cementicios se llevó a cabo en dos etapas. En la primera etapa, debido a su fina granulometría, se utilizó el DMS-0 para evaluar su influencia sobre la fluidez de la pasta de cemento. Por lo tanto, se asumió que su incorporación podría tener un papel como adición. También se usó el material DMS-0 para la producción de mortero en sustitución de la arena natural de 0/2 mm (se empleó un tamaño de partículas similar para la construcción de los pavimentos portuarios de hormigón descritos en Limeira et al (26)), para evaluar el efecto que tiene como corrector granular en las propiedades en estado endurecido de los morteros. El objetivo era definir la proporción de sustitución óptima para utilizar el máximo porcentaje de DMS.

En la segunda etapa, se utilizaron los tres materiales de DMS obtenidos en el puerto de Barcelona (DMS-A, DMS$B$ y DMS-C) para la producción de morteros en sustitución parcial de arenas naturales de fracción 0/5 mm, el tamaño de fracción habitual para la producción de hormigón. También se evaluaron las propiedades mecánicas para validarlos como componentes adecuados. Luego se compararon los resultados con los de los morteros convencionales y se determinó la proporción de sustitución óptima. studied material yields final properties compatible with the usual design requirements. The cement-based treatment $(23,24)$ is a well-known technique applied to the treatment of dredged sediments. Its main objective is to improve the packing and the compressive properties required for geotechnical applications. In case of contaminated material, some decontamination techniques (25), like the stabilization of heavy metals and organic thermal elimination, are often used.

A pilot experiment at industrial scale has been developed with DMS as constructive material for the execution of three sections of harbor concrete pavements as described in Limeira et al (26). That work assesses DMS used as a fine granular corrector with $18 \%$ of raw sand 0/2 mm substitution (by weight) in the concrete dosage.

In this research work, the DMS materials obtained from two different Spanish ports (DMS-0 from the Port of Sant Carles de la Ràpita and DMS-A, DMS-B and DMS-C from the Port of Barcelona) were used as a component material for pastes and mortars production; DMS was used as addition by cement weight and in partial substitution of raw sand with different grading in order to validate its influence on those cementitious materials. The chemical, physical and mechanical characteristics of all DMS materials were determined and evaluated so as to fulfill and observe the aggregates requirements for the production of cementitious materials.

The experimental phase of cementitious materials was carried out in two stages. In stage 1, due to its fine grading, the DMS-O was used in order to evaluate its influence on the fluidity of the cement paste. Hence, its incorporation was assumed to play a role as an addition. The DMS-0 material was also used for mortar production in substitution of $0 / 2 \mathrm{~mm}$ raw sand (a similar grading size was used in the construction of the harbor concrete pavements described in Limeira et al (26)), so as to evaluate its effect as a granular corrector in the hardened properties of mortars. The goal was to define the optimum substitution ratio in order to use the maximum percentage of DMS for concrete production.

In stage 2, the three DMS materials (DMS-A DMS- $B$ and $D M S-C$ ) obtained from the Port of Barcelona were used for mortar production in partial substitution of $0 / 5 \mathrm{~mm}$ fraction raw sands, the usual fraction size for concrete production. In addition, mechanical properties were tested in order to validate them as adequate components. Then, the results were compared to those of conventional mortars and the optimum substitution ratio was determined. 


\section{MATERIALES Y PROGRAMA EXPERIMENTAL}

\subsection{Materiales}

Con respecto a la procedencia del material DMS, el DMS-0 se obtuvo de un volumen de descarga de $350.000 \mathrm{~m}^{3}$ extraídos por una draga Josefa Pérez 5A-CA-4-93 y acopiados para su secado al aire libre durante tres meses en el puerto de Sant Carles de la Ràpita de Tarragona. DMSA, DMS-B y DMS-C se obtuvieron de dos lugares distintos del puerto de Barcelona tras su almacenamiento al aire libre durante seis meses: DMS-A y DMS-B fueron extraídos de dos capas de la misma zona de descarga; DMS-A fue extraído de la capa superficial con una exposición permanente al aire; y DMS-C proviene de la zona de descarga utilizada para la recuperación de tierras por relleno hidráulico. Los DMS no fueron sometidos a ningún tratamiento ni proceso de lavado o secado durante este estudio.

Para todos los materiales cementicios se utilizó cemento Portland 42.5R tipo II, mientras que para la producción de mortero se empleó arena caliza natural de machaqueo. Además, se usó un aditivo plastificante $(P)$ en algunas pastas para evaluar la fluidez y la cohesión.

\subsubsection{Caracterización física y química de las arenas naturales y los materiales DMS}

En la Tabla 1 de este trabajo se resumen las propiedades físicas según la UNE-EN 1097-6 (27) con respecto a arenas naturales (fracciones NS1 0/2 mm y NS2 0/5 mm) y arenas de dragado marino (DMS-0, DMS-A, DMS-B y DMS-C). Como se puede observar en la Figura 1, DMS-0, DMS-A, DMS-B y DMS-C presentaron una granulación arenosa similar (más del $80 \%$ pasa por el tamiz \# $500 \mu \mathrm{m})$ con una fracción de cal + arcilla despreciable (< tamiz \# $63 \mu \mathrm{m}$ ) excepto en el caso de DMS-A, que presentó un $14 \%$. Se determinó la granulación de acuerdo con las especificaciones de la UNE-EN 933-1 (28). El despreciable contenido de conchas observado en todos los DMS utilizados en este estudio podría estar relacionado con las sucesivas actividades de mantenimiento llevadas a cabo en los puertos estudiados. Todas las propiedades se obtuvieron con la media de tres valores.

\section{MATERIALS AND EXPERIMENTAL PROGRAM}

\subsection{Materials}

With respect to the provenance of the DMS material, DMS-O was obtained from a disposal volume of $350000 \mathrm{~m}^{3}$ extracted by a Josefa Pérez 5A-CA-4-93 dredger and stockpiled for drying in the open air for three months at the Port of Sant Carles de la Ràpita in Tarragona. DMS-A, DMS-B and DMS-C were obtained from two different sites at the Port of Barcelona after their disposal in the open air for 6 months: DMS-A and $D M S-B$ were extracted from two layers of the same disposal site; DMS-A was cast in the surface layer with permanent air exposure; and DMS-C comes from the disposal site used for hydraulic fill reclamation. The DMS were not subjected to any treatment, washing or drying process during this study.

Type II Portland cement 42.5R was used in all cemetitious materials, while raw crushed limestone sand was used for mortar production. Furthermore, commercial plasticizer $(P)$ was used in some pastes in order to evaluate fluidity and cohesion.

\subsubsection{Physical and chemical characterization of raw sands and DMS materials}

This work summarizes in Table 1 the physical properties according to UNE-EN 1097-6 (27) regarding raw sands (NS1 0/2 $\mathrm{mm}$ and NS2 0/5 $\mathrm{mm}$ fractions) and dredged marine sands (DMS-0, DMS-A, DMS-B and DMS-C). As shown in Figure 1, DMS-0, DMS- $A$, DMS- $B$ and DMS-C showed a similar sandy grading (more than $80 \%$ passes through a \# $500 \mu \mathrm{m}$ sieve) with a negligible lime + clay fraction (< \#63 $\mu \mathrm{m}$ sieve) except for DMS-A, which showed a $14 \%$. The grading was determined according to the UNE-EN 933-1 (28) specifications. The negligible shell content observed in all the DMS used in this study might be related to the successive maintenance activities carried out in the ports studied. All properties were obtained with the average of three values.

Tabla 1 / Table 1

Densidad y absorción de los áridos.

Density and absorption of the aggregates.

\begin{tabular}{|c|c|c|c|c|c|c|}
\hline & NS1 & NS2 & DMS-0 & DMS-A & DMS-B & DMS-C \\
\hline Densidad / Density* (kg/dm $\left.{ }^{3}\right)$ & 2.65 & 2.69 & 2.63 & 2.57 & 2.57 & 2.67 \\
\hline Absorción / Absorption (\%) & 0.4 & 1.9 & 1 & 1.7 & 0.8 & 1 \\
\hline
\end{tabular}

* Densidad en superficie seca y saturada. / Density on a saturated and surface - dried basis. 


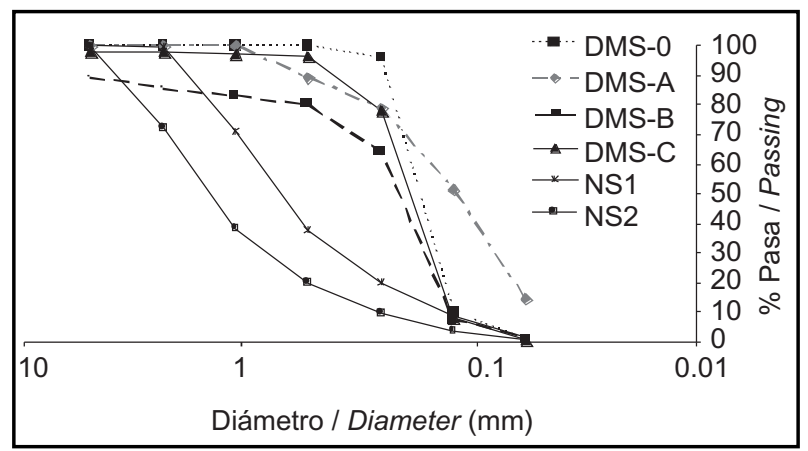

Figura 1. Granulometría del árido fino.

Figure 1. Fine aggregate grading.

Los resultados del análisis químico de DMS-0 (del puerto de Sant Carles de la Ràpita) y DMS (del puerto de Barcelona) se obtuvieron con la media de cinco y tres probetas de cada material, respectivamente. Los resultados obtenidos se presentan en las Tablas de la 2 a la 4 . Estas probetas se obtuvieron muestreando $1 \mathrm{~m}^{3}$ de cada DMS extraído de las zonas de acopio en el puerto. Para determinar posibles componentes contaminantes, se realizó un exhaustivo muestreo de acuerdo con las especificación UNE-EN 932-1 (29). El análisis químico determina que el componente primario del DMS es el cuarzo $\left(\mathrm{SiO}_{2}\right)$, y el segundo es la calcita $\left(\mathrm{CaCO}_{3}\right)$, como muestra la Tabla 2.

Los contenidos de metales pesados se determinaron mediante espectrometría de emisión atómica (ICP). Se prepararon las probetas siguiendo las recomendaciones de la Unión Europea (30). De acuerdo con las "Recomendaciones para la Gestión del Material Dragado en los Puertos Españoles" dictadas por el Centro de Estudios y Experimentación de Obras Públicas (CEDEX) (31), la cantidad de metales determinada estaba por debajo del límite exigido por el Nivel de Acción 1 (ver Tabla 3). Los niveles del 1 al 3 corresponden al rango gradual de límites de concentración de sustancias tóxicas con respecto a la autorización para materiales dragados de vertederos en España.
The results of the chemical analysis of DMS-0 (from the Port of Sant Carles de la Ràpita) and DMS (from the Port Barcelona) were given by the average of five and three samples of each material, respectively. The results obtained are shown in tables 2 to 4. These samples for testing were obtained by sampling $1 \mathrm{~m}^{3}$ of each DMS extracted from stockpiles at the harbor site. In order to determine possible contaminant components, exhaustive sampling was carried out according to the UNE-EN 932-1 (29) specification. The chemical analysis determines that the primary component of DMS is quartz $\left(\mathrm{SiO}_{2}\right)$ and the second one is calcite $\left(\mathrm{CaCO}_{3}\right)$, as shown in Table 2.

Heavy metal contents were determined by atomic emission spectrometry (ICP). The samples were prepared following European Union recommendations (30). In accordance with the "Recommendations for the Management of Dredged Material in Spanish ports" given by the Centre for Studies and Experimentation of Public Works CEDEX (31), the quantity of metals determined was under the limit required by the first level of action (see Table 3). Levels one to three correspond to the gradual rank of concentration limits of toxic substances regarding the authorization for landfill dredged materials in Spain.

Tabla 2 / Table 2

Caracterización mineralógica de DMS-0, DMS-A, DMS-B Y DMS-C mediante difracción de rayos $\mathrm{X}$. Mineralogical identification of DMS-0, DMS-A, DMS-B AND DMS-C SAMPLES, by X-ray diffraction.

\begin{tabular}{|c|c|c|c|c|}
\hline Mineral & DMS-0 & DMS-A & DMS-B & DMS-C \\
\hline Calcita / Calcite $\mathrm{CaCO}_{3}$ & $\mathrm{xx}$ & $\mathrm{xxx}$ & $\mathrm{xx}$ & $\mathrm{xx}$ \\
\hline Cuarzo / Quartz $\mathrm{SiO}_{2}$ & $\mathrm{xx}$ & $\mathrm{xxx}$ & $\mathrm{xxx}$ & $\mathrm{xxx}$ \\
\hline Halita / Halite $\mathrm{NaCl}$ & $\mathrm{x}$ & $\mathrm{xx}$ & $\mathrm{x}$ & $\mathrm{x}$ \\
\hline Dolomita / Dolomite $\mathrm{MgCa}\left(\mathrm{CO}_{3}\right)_{2}$ & $\mathrm{x}$ & $\mathrm{xx}$ & $\mathrm{xx}$ & $\mathrm{x}$ \\
\hline Mica Moscovita / Mica Muscovite $\mathrm{KMgAlSi}_{4} \mathrm{O}_{10}(\mathrm{OH})_{2}$ & $\mathrm{x}$ & $\mathrm{x}$ & $\mathrm{x}$ & $\mathrm{x}$ \\
\hline Albita / Albite $\mathrm{NaAlSi}_{3} \mathrm{O}_{8}$ & $\mathrm{x}$ & $\mathrm{x}$ & $\mathrm{x}$ & $\mathrm{xx}$ \\
\hline Sanidina / Sanidina $\left(\mathrm{Na}_{1} \mathrm{~K}_{\mathrm{AlSi}} \mathrm{O}_{8}\right.$ & $\mathrm{x}$ & $\mathrm{x}$ & - & $\mathrm{x}$ \\
\hline Hidrofilita / Hidrofilita $\mathrm{CaCl}_{2}$ & $\mathrm{x}$ & $\mathrm{xx}$ & $\mathrm{x}$ & $\mathrm{x}$ \\
\hline Orthoclase / Orthoclase $\mathrm{KAIS}_{3} \mathrm{O}_{8}$ & - & - & $\mathrm{x}$ & $\mathrm{x}$ \\
\hline Carolinian / Carolinian $\mathrm{Al}_{2} \mathrm{Si}_{2} \mathrm{O}_{5}(\mathrm{OH})_{4}$ & $\mathrm{x}$ & $\mathrm{x}$ & $\mathrm{x}$ & $\mathrm{x}$ \\
\hline
\end{tabular}

Clave: $\mathrm{xxx}$, componentes mayoritarios; $\mathrm{xx}$, componentes secundarios; $\mathrm{x}$, componentes minoritarios o posibles. / Key: $x x x$, major components; $x x$, secondary components; $x$, minority components or possible. 
Tabla 3 / Table 3

Metales pesados $(\mu \mathrm{g} / \mathrm{g})$, materia orgánica total $(\mathrm{OM})$ y carbonatos presentes en muestras de DMS. Heavy metals $(\mu \mathrm{g} / \mathrm{g})$, total organic matter $(\mathrm{OM})$ and carbonates in DMS samples.

\begin{tabular}{|c|c|c|c|c|c|c|c|c|c|c|}
\hline Muestras / Samples & Cd & $\mathrm{Cu}$ & $\mathrm{Zn}$ & $\mathrm{Cr}$ & $\mathrm{Ni}$ & As & $\mathrm{Hg}$ & $\mathrm{Pb}$ & OM (\%) & $\begin{array}{c}\text { Carbonatos I } \\
\text { Carbonates } \\
\left(\% \mathrm{CaCo}_{3}\right)\end{array}$ \\
\hline DMS-0 & 0.06 & 3.92 & 26.27 & 29.76 & 12.58 & 3.50 & 0.03 & 91.38 & 0.76 & 38.01 \\
\hline DMS-A & nd & 12.07 & 34.77 & 42.13 & 13.10 & nd & nd & 7.37 & 0.77 & 39.75 \\
\hline DMS-B & nd & 4.10 & 15.27 & 20.27 & 5.10 & nd & nd & 7.27 & 1.02 & 26.04 \\
\hline DMS-C & nd & 6.47 & 13.77 & 20.83 & 6.20 & nd & nd & 7.40 & 0.88 & 29.31 \\
\hline Nivel de acción 1 / Level of Action 1 & 1 & 100 & 500 & 200 & 100 & 80 & 0.60 & 120 & $1 \%$ & na \\
\hline
\end{tabular}

Valores resultantes de DMS-0 son el promedio de cinco datos, valores resultantes de DMS-A, DMS-B y DMS-C son el promedio de tres datos (nd = non detectado; $\mathrm{na}=$ no disponible). / DMS-0 values result from five average data; $D M S-A, D M S-B$ and $D M S-C$ values result from three average data ( $n d=$ not detected, na $=$ not available).

El contenido de material orgánico se determinó mediante el análisis térmico y los resultados obtenidos aparecen en la Tabla 3. Es evidente que todos los materiales DMS contenían materia orgánica similar así que la variación de los resultados fue muy baja. Los ensayos basados en las recomendaciones del CEDEX (31) revelaron que los valores de bifenilos policlorados (PCB) (sedimento seco $<63 \mu \mathrm{m}$ expresados por $\mathrm{ng} / \mathrm{g}$ ) fueron más bajos que los del Nivel de Acción 1 en todas las probetas $(<0,1)$.

La Tabla 4 muestra las concentraciones de cloruro y sulfato detectadas en los materiales DMS. Las cinco probetas de DMS-0 analizadas presentaron una cantidad muy baja de estos componentes y todos los valores estuvieron por debajo de las exigencias máximas establecidas por la Instrucción Española de Hormigón Estructural (EHE) (32), que define los requisitos más exigentes para materiales constructivos. Por otra parte, el contenido máximo de cloruro soluble en agua en los áridos para hormigón armado no debe sobrepasar el 0,05\%, mientras que el contenido máximo de sulfato soluble en ácido en los áridos no debe sobrepasar el 0,8\% de la masa de los áridos.

En lo que concierne a la concentración de cloruro soluble en los tres DMS provenientes del puerto de Barcelona, las probetas carecían de homogeneidad, ya que DMS-A sobrepasaba 10 veces los resultados obtenidos por DMS-B y DMS-C (ver Tabla 4). Los resultados están expresados en gramos de ión de cloruro por $100 \mathrm{~g}$ de
The organic material content was determined by thermal analysis and the results obtained are shown in Table 3. It is evident that all the DMS materials contained similar organic matter and the variation of the results was very low. Tests based on CEDEX (31) recommendations revealed that polychlorinated biphenyls ( $\left.P C B^{\prime} s\right)$ values (dry sediment < $63 \mu \mathrm{m}$ expressed by $\mathrm{ng} / \mathrm{g}$ ) were lower than those at the first level of action in all samples $(<0.1)$.

The chloride and sulfate concentrations detected in DMS materials are shown in Table 4. The five samples of DMS-O analyzed showed a very low quantity of these components and all values were lower than the maximum requirements defined by the Spanish standard of structural concrete (32), which defines the most demanding requirements for construction materials. On the one hand, maximum water soluble chloride content in aggregates for reinforced concrete should not exceed $0.05 \%$ and on the other hand, maximum acid soluble sulfate content on aggregates should not exceed $0.8 \%$ of the mass of the aggregates.

As regards soluble chloride concentration in the three DMS from the Port of Barcelona, the samples lacked homogeneity, with DMS-A exceeding 10 times the results obtained by DMS-B and DMS-C (see Table 4). Results are expressed in grams of chloride ion by $100 \mathrm{~g}$ of dry material. An estimated average is presented in

Tabla 4 / Table 4

Cloruros solubles en agua y sulfatos presentes en las muestras de DMS.

Chlorides soluble in water and sulfates, in DMS samples.

\begin{tabular}{|c|c|c|}
\hline Muestras / Samples & $\mathrm{Cl}^{-}(\%)$ & $\mathrm{SO}_{3}(\%)$ \\
\hline DMS-0 & 0.01 & 0.04 \\
\hline DMS-A & 1.70 & 0.23 \\
\hline DMS-B & 0.13 & 0.16 \\
\hline DMS-C & 0.10 & 0.46 \\
\hline Límite / Limit & $\begin{array}{c}\mathrm{Cl}^{-}(\%)<0.05 \% \text { peso de áridos / mass of the } \\
\text { aggregates }\end{array}$ & $\begin{array}{c}\mathrm{SO}_{3}<0.8 \% \text { peso de áridos / mass of the } \\
\text { aggregates }\end{array}$ \\
\hline
\end{tabular}


material seco. Se presenta una media estimada en porcentaje ya que se observó una gran dispersión. Todos los resultados obtenidos con los DMS del puerto de Barcelona sobrepasaron los valores máximos permitidos por la EHE (32). El alto contenido de cloruro hallado en las probetas de DMS-A probablemente era debido a que procedía de la capa superficial de vertido, que presenta un mayor contenido de finos y peores condiciones de secado (10). A causa del probablemente alto nivel de concentración de cloruro en los materiales de DMS, estos se deben mezclar con áridos naturales en un porcentaje adecuado para mantener los requisitos estándar.

Los resultados de la concentración de sulfato en las tres probetas de DMS procedentes del puerto de Barcelona arrojaron contenidos significativos; sin embargo, los valores eran más bajos que los permitidos por la EHE, la Instrucción Española de Hormigón Estructural (32), que establece un $0,8 \%$ de sulfato soluble en ácido por la masa de los áridos. Los resultados oscilaron entre el $0,11 \%$ y el $0,72 \%$.

\subsection{Programa experimental}

Tal y como se ha mencionado anteriormente, el trabajo experimental se realizó en dos fases. En primer lugar, durante la fase 1 se examinó la influencia del material DMS-0 sobre las propiedades de la pasta de cemento (usada como adición) y sobre los morteros (empleados como correctores granulares en sustitución parcial de arena natural con fracción $0 / 2 \mathrm{~mm}$ ). En segundo lugar, en la fase 2 se analizaron los materiales DMS procedentes del puerto de Barcelona utilizados en sustitución parcial de arena natural $0 / 5 \mathrm{~mm}$ para verificar las propiedades en estado endurecido de los morteros. Las pastas y los morteros se fabricaron en una mezcladora del tipo Hobart con capacidad de 5 litros y dos velocidades, de acuerdo con las especificaciones de la instrucción ASTM C 305 (33), en un laboratorio con una temperatura ambiente de $20 \pm 2{ }^{\circ} \mathrm{C}$.

\subsubsection{Experimentos de la fase 1}

Debido a sus propiedades físicas (tamaño de los granos), el material DMS tiene una importante influencia sobre la trabajabilidad de la pasta de cemento. Por lo tanto, para medir esa influencia en la consistencia, fluidez y cohesión de la matriz del cemento, se llevaron a cabo ensayos de consistencia normal (34), cono de Marsh (35) y minislump (36) en pastas fabricadas con diferentes porcentajes de DMS-0 como adición o en sustitución parcial del cemento. El ensayo del cono de Marsh lo han utilizado muchos investigadores $(37,38)$ en el estudio de la fluidez para determinar el contenido apropiado de plastificantes en las mezclas. El ensayo consiste en preparar 1 litro de pasta y medir el tiempo que tarda 1/2 litro de percentage since high dispersion was observed. All results obtained in the DMS from the Port of Barcelona exceeded the maximum values allowed by EHE (32). The high amount of chloride in DMS-A samples was probably due to the fact that it was obtained from the surface disposal layer which features higher fine content and worse drying conditions (10). Due to the probably high amount of chloride concentration in DMS materials, they must be mixed with raw aggregates at an adequate percentage so as to maintain the standard requirements.

The sulfate concentration in the three DMS samples from the Port of Barcelona presented significant content results; however, the values were lower than those allowed by EHE - Spanish standard of structural concrete (32) which states $0.8 \%$ of sulfate, soluble in acid, by the mass of aggregates. The results ranged from $0.11 \%$ to $0.72 \%$.

\subsection{Experimental program}

As mentioned above, the experimental work was carried out in two stages. Firstly, stage 1 examined the influence of DMS-0 material on the properties of cement paste (used as addition) and on mortars (used as granular corrector in partial substitution of 0/2 $\mathrm{mm}$ fraction raw sand). Secondly, stage 2 analyzed DMS materials from the port of Barcelona used in partial substitution of $0 / 5 \mathrm{~mm}$ raw sand in order to verify the hardened properties of mortars. The pastes and mortars were produced in a 5-liter Hobart-type blender with two-speed capacities in accordance with ASTM C 305 specifications (33), at a laboratory with a room temperature of $20 \pm 2^{\circ} \mathrm{C}$.

\subsubsection{Stage 1 experiments}

Due to its physical properties (grading size), DMS material has an important influence on the workability of cement paste. Therefore, in order to measure that influence on the consistency, fluidity and cohesion of the cement matrix, normal consistency (34), Marsh cone (35) and minislump (36) tests were carried out in pastes made with different percentage of DMS-0 as addition or in partial substitution of cement. The Marsh cone test has been used by many researchers $(37,38)$ in the study of fluidity to determine the appropriate content of plasticizers in the mixes. The test consists in preparing 1 liter of paste and measuring the time it takes for 1/2 liter of the paste to flow through the needle. The procedure 
pasta en atravesar la aguja. El procedimiento del ensayo minislump se describe en Aitcin (36) y consiste en llenar el mini-cono con pasta y registrar el tiempo de extensión en segundos a los $10 \mathrm{~min}, 30 \mathrm{~min}, 40 \mathrm{~min}$ y $60 \mathrm{~min}$ desde la fabricación de la mezcla. Una extensión final de 180 $\pm 10 \mathrm{~mm}$ y un correspondiente tiempo de extensión de hasta $115 \mathrm{~mm}\left(\mathrm{~T}_{115}\right)$ alrededor de $3 \pm 1$ segundos indica una cohesión aceptable para mezclas con una proporción relleno/cemento óptima.

La influencia de los diferentes contaminantes presentes en los materiales DMS-0 (como, por ejemplo, los cloruros) sobre la aceleración o desaceleración del proceso de hidratación del cemento (12) se estudió en morteros mediante evolución térmica. Se registraron los datos con una sonda termopar tipo $\mathrm{K}$ a intervalos de registro de 60 segundos en las primeras 12 horas desde la fabricación. Se utilizó un aparato Squirrel a una temperatura ambiente de $20 \pm 2{ }^{\circ} \mathrm{C}$ para determinar el posible papel del DMS-0 en la cinética de las reacciones de hidratación.

Para evaluar su efecto en las propiedades en estado endurecido de los morteros, se utilizó DMS-0 en sustitución parcial $(25 \%$ y $50 \%)$ de la arena natural con una fracción de $0 / 2 \mathrm{~mm}$. Se realizaron ensayos de resistencia a compresión y de flexo-tracción (39) a las edades de 7 y 28 días en probetas prismáticas de 40 × 40 x $160 \mathrm{~mm}$ sometidas a vibración estándar y curado húmedo.

\section{Proporciones de mezcla de las pastas}

Todas las pastas se fabricaron con DMS-0 como adición o con sustitución parcial del cemento, excepto en el caso de las mezclas de control (PN1 y P1), en las que no se usó DMS-0. En algunas pastas se incluyó aditivo plastificante para evaluar la fluidez y la cohesión. La Tabla 5 describe las proporciones de las mezclas de las pastas estudiadas.

Las pastas PN1, PN2 y PN3 se fabricaron empleando DMS-0 con tasas de sustitución de cemento (por peso) del $0 \%$, $25 \%$ y $50 \%$, respectivamente, y fueron sometidas al ensayo de consistencia normal. En las pastas P1, P2 y P3 se incorporó un $0 \%, 25 \%$ y $50 \%$ de DMS-0 como of the mini slump test is described in Aitcin (36) and consists in filling the minis/ump with paste and recording the extension time in seconds at $10 \mathrm{~min}, 30 \mathrm{~min}, 40 \mathrm{~min}$ and 60 min from the mix fabrication. A final spread of $180 \pm 10 \mathrm{~mm}$ and a corresponding spread time reaching $115 \mathrm{~mm}\left(T_{115}\right)$ around $3 \pm 1$ seconds indicates acceptable cohesion for mixes with an optimum filler/cement ratio.

The influence of different contaminants present in DMS0 materials (such as chlorides) on the acceleration or retarding of the process of cement hydration (12) was studied in mortars through thermal evolution. The data was recorded by using a $K$ thermo par probe at recording intervals of 60 seconds in the first 12 hours of fabrication. The Squirrel apparatus was used at a room temperature of $20 \pm 2{ }^{\circ} \mathrm{C}$ in order to determine the possible role of DMS-0 in the kinetics of hydration reactions.

In order to assess its effect on the hardened properties of mortars, DMS-0 was used in partial substitution (25\% and $50 \%$ ) of raw sand with a $0 / 2 \mathrm{~mm}$ fraction. Compressive and flexural strength tests (39) were carried out at the age of 7 and 28 days on prismatic samples of $40 \times 40 \times 160 \mathrm{~mm}$ subjected to standard vibration and moist curing.

\section{Mix proportions of pastes}

All pastes were made with DMS-0 as addition or with partial cement substitution, except for control mixes (PN1 and P1), where no DMS-0 was used. Plasticizer content was used in some pastes in order to assess fluidity and cohesion. Table 5 describes the mix proportions of the pastes studied.

Pastes PN1, PN2 and PN3 were produced using DMS-0 with $0 \%, 25 \%$ and $50 \%$ of cement substitution ratios (by weight), respectively, and were submitted to the normal consistency test. Pastes P1, P2 and P3 incorporated 0\%, $25 \%$ and $50 \%$ of DMS- 0 as addition, respectively, by

Tabla 5 / Table 5

Dosificación de las pastas estudiadas.

Mix composition of the pastes studied.

\begin{tabular}{|c|c|c|c|c|c|c|}
\hline \multirow[t]{2}{*}{ Materiales / Materials } & \multicolumn{3}{|c|}{ Consistencia normal / Normal consistency } & \multicolumn{3}{|c|}{$\begin{array}{l}\text { Cono de Marsh y minislump / } \\
\text { Marsh cone and mini slump }\end{array}$} \\
\hline & PN1 & PN2 & PN3 & P1 & $\mathbf{P 2}$ & P3 \\
\hline Cemento / Cement (gr) & 500 & 375 & 250 & 1200 & 1200 & 1200 \\
\hline DMS-0 (gr) & 0 & 125 & 250 & - & 300 & 600 \\
\hline Agua / Water & 120 & 100 & 90 & 600 & 600 & 600 \\
\hline$w / c$ & 0.24 & 0.27 & 0.36 & 0.5 & 0.5 & 0.5 \\
\hline$\% \mathrm{P}$ & - & - & - & $0-0.5-1$ & $0.5-1$ & $0.5-1-2$ \\
\hline
\end{tabular}


adición por peso del cemento, respectivamente. Estas pastas se fabricaron para evaluar la fluidez y cohesión mediante los ensayos del cono de Marsh y el minislump. En mezclas posteriores se utilizaron diferentes contenidos de plastificante (\%P) que oscilaban entre el $0 \%$ y el $1 \%$ por peso del cemento, así como una proporción $\mathrm{a} / \mathrm{c}=0,5$ constante.

\section{Proporciones de mezcla de los morteros}

Se fabricaron tres morteros iniciales con tasas graduales de sustitución de la arena natural NS1 0/2 mm por DMS0 . En todos los casos se adoptó una dosificación de 1:3:0,5 (cemento:arena:agua) para las proporciones de la mezcla de los morteros. No se utilizó contenido plastificante (\%P) en los morteros, mientras que la proporción a/c se mantuvo constante en 0,50 con respecto al contenido de cemento. Los morteros M1, M2 y M3 fueron fabricados con sustitución parcial de arena NS1 0/2 mm por DMS-0. La mezcla M1 corresponde a la mezcla de control en la que no se incorporó DMS-0, mientras que las mezclas M2 y M3 corresponden a mezclas en las que se sustituyó un contenido del $25 \%$ y $50 \%$ de arena natural NS1 0/2 mm por DMS-0.

\subsubsection{Experimentos de la fase 2}

Se utilizaron DMS-A, DMS-B y DMS-C en morteros con sustitución parcial (5\%, 15\% y 25\%) de arena natural NS2 0/5 mm. Se evaluaron las propiedades en estado endurecido mediante ensayos de resistencia a compresión y de flexo-tracción (39) a las edades de 7 y 28 días en probetas prismáticas de $40 \times 40 \times 160 \mathrm{~mm}$ sometidas a vibración estándar y curado húmedo.

\section{Composición de la mezcla de los morteros}

Se fabricaron una serie de morteros con una sustitución gradual de la arena natural NS2 0/5 mm por DMS-A, DMS$B$ y DMS-C. En la fabricación de los morteros no se empleó contenido plastificante. Los morteros MA-1, MA-2, MA-3, MB-1, MB-2, MB-3, MC-1, MC-2 y MC-3 corresponden a las mezclas con sustitución de la arena natural NS2 0/5 mm por materiales DMS. Los índices 1,2 y 3 se refieren respectivamente a las proporciones de sustitución del $5 \%$, $15 \%$ y $25 \%$ de la arena NS2 $0 / 5 \mathrm{~mm}$ por DMS. A, B y C hacen referencia al uso de DMS-A, DMS-B y DMS-C, respectivamente. El mortero de control REF se fabricó con arena natural NS2 0/5 mm sin incorporación de DMS. A las edades de 7 y 28 días, se ensayaron probetas prismáticas de 40 × 40 × $160 \mathrm{~mm}$ sometidas a vibración estándar y curado húmedo, de acuerdo con la norma EN-UNE 196-1 (39). El principal objetivo era determinar la proporción de sustitución óptima de la arena natural, así como evaluar las propiedades en estado endurecido de los morteros fabricados con diferentes DMS. cement weight. They were fabricated in order to evaluate fluidity and cohesion through Marsh cone and mini slump tests. Plasticizer content $(\% P)$ varying from $0 \%$ to $1 \%$ by cement weight as well as constant $\mathrm{w} / \mathrm{c}=$ 0.5 were used in the latter mixes.

\section{Mix proportions of mortars}

Three initial mortars were produced with gradual substitution ratios of raw sand NS1 0/2 mm for DMS-0. In all cases, a dosage 1:3:0.5 (cement:sand:water) was adopted for the mix proportions of the mortars. Plasticizer content (\%P) was not used in mortars, while the $w / c$ ratio was constant at 0.50 with regard to the cement content. Mortars M1, M2 and M3 were made with partial replacement of NS1 0/2 $\mathrm{mm}$ sand by DMS-0. M1 mix refers to a control mix in which no DMS-0 was incorporated, whereas M2 and M3 mixes correspond to mixes where $25 \%$ and $50 \%$ of raw sand NS1 0/2 mm content was replaced by DMS-0.

\subsubsection{Stage 2 experiments}

DMS- $A$, DMS- $B$ and DMS-C were used in mortars with partial substitution (5\%, $15 \%$ and $25 \%$ ) of raw sand NS2 $0 / 5 \mathrm{~mm}$. Hardened properties were assessed through compressive and flexural strength tests (39) at the age of 7 and 28 days on prismatic samples with $40 \times 40 \times$ $160 \mathrm{~mm}$ subjected to standard vibration and moist curing.

\section{Mix composition of mortars}

$A$ series of mortars were made with gradual raw sand NS2 0/5 mm substitution by DMS-A, DMS-B and DMS-C. No plasticizer content was used in the mortars fabrication. Mortars MA-1, MA-2, MA-3, MB-1, MB-2, $M B-3, M C-1, M C-2$ and $M C-3$ refer to mixes with raw sand NS2 0/5 $\mathrm{mm}$ replacement by DMS materials. The indices 1,2 and 3 refer to $5 \%, 15 \%$ and $25 \%$ substitution ratio of raw sand NS2 0/5 mm for DMS, respectively. $A, B$ and $C$ stand for the use of DMS-A, DMS-B and DMS-C, respectively. Control mortar REF was made with raw sand NS2 0/5 $\mathrm{mm}$ and no DMS incorporation. At the age of 7 and 28 days, prismatic samples of $40 \times 40 \times 160 \mathrm{~mm}$ subjected to standard vibration and moist curing were tested according to EN-UNE 196-1 (39). The main objective was to determine the optimum raw sand substitution ratio as well as to assess the hardening properties of mortars made with different DMS. 


\section{RESULTADOS Y DISCUSIÓN}

\subsection{Fase 1}

\subsubsection{Pastas}

\section{Consistencia normal}

Para obtener la consistencia normal en las pastas PN1, PN2 y PN3 (con sustitución del 0\%, 25\% y $50 \%$ del cemento por DMS-0), se aumentó la proporción aguacemento de 0,24 a 0,27 en PN2, y a 0,36 en PN3. Los resultados indican un leve aumento de la demanda de agua para PN2, al contrario que la mezcla control PN1. Por otra parte, PN3 presentó la mayor demanda de agua de todas las mezclas ensayadas. La utilización de mayores porcentajes de material DMS requería un mayor contenido de agua para obtener la consistencia normal.

\section{Cono de Marsh}

En las pastas P2 y P3 con una proporción $\mathrm{a} / \mathrm{c}=0,5$ constante se incorporaron un $25 \%$ y $50 \%$, respectivamente, de DMS-0 como adición por peso del cemento con el objetivo de verificar el efecto de DMS-0 sobre la fluidez de las mezclas en comparación con la mezcla de control P1. En la Tabla 6 y Figura 2 se puede observar que, una vez que el contenido de DMS-0 aumenta, la fluidez de la mezcla disminuye. Sin embargo, el tiempo de flujo de P2 (14 segundos) presentó una variación despreciable en comparación con la mezcla de control P1 (10 segundos) cuando se incorporó a la pasta un 1\% del contenido plastificante. No obstante, se observó un comportamiento diferente en las mezclas P3, ya que sus tiempos de flujo presentaron un aumento considerable. En la mezcla P3 fue necesario un contenido plastificante del $2 \%$ para conseguir un tiempo de flujo similar en comparación con la mezcla de control. Esto pone de relieve la influencia de DMS-0 en la pérdida de fluidez de las mezclas una vez que se aumenta su proporción de incorporación.

\section{RESULTS AND DISCUSSION}

\subsection{Stage 1}

\subsubsection{Pastes}

\section{Normal consistency}

In order to obtain the normal consistency on pastes PN1, PN2 and PN3 (with replacement of 0\%, 25\% and 50\% of cement by DMS-0), the water-cement ratio was increased from 0.24 to 0.27 in PN2, and to 0.36 in PN3. The results indicate a slight increase in water demand for $P N 2$, in opposition to control mix PN1. On the other hand, PN3 presented the highest water demand out of all the mixes tested. The use of higher percentages of DMS materials required higher water content so as to obtain the normal consistency.

\section{Marsh cone}

Pastes $P 2$ and $P 3$ with a constant $w / c=0.5$ incorporated $25 \%$ and $50 \%$, respectively, of DMS-0 as addition by cement weight with the aim of verifying the effect of DMS-O on the fluidity of the mixes in comparison to the control mix P1. In Table 6 and Figure 2 it can be observed that, once the DMS- 0 content rises, the mix fluidity diminishes. However, the P2 flow time (14 sec) showed a negligible variation, in comparison to the control mix P1 (10 sec), when $1 \%$ of the plasticizer content was incorporated into the paste. However, a different behavior was observed in the P3 mixes, for its flow times showed a considerable increase. An amount of $2 \%$ of plasticizer content was necessary for the $P 3$ mix in order to achieve a similar flow time in comparison to the control mix. This highlights the influence of DMS-0 on the fluidity loss of the mixes once its incorporation ratio was increased.

Tabla 6 / Table 6

Resultados del ensayo de minislump en pastas. Mini slump test results on pastes.

\begin{tabular}{|c|c|c|c|c|c|c|c|c|c|c|}
\hline \multicolumn{10}{|c|}{ Winislump en pastas / Mini Slump Pastes } \\
\hline \multicolumn{9}{|c|}{ P1 (0.5 DMS-0) } \\
\hline $\mathbf{d}(\mathbf{c m})$ & \multicolumn{3}{|c|}{ P2 (25\% DMS-0) } & \multicolumn{4}{c|}{ P3 (50\% DMS-0) } \\
\hline $\mathrm{d}_{10}=$ & 10.10 & 8.5 & 7.65 & 9.0 & 10.0 & 12.5 & 8.4 & 8.6 & 10.0 & 11.0 \\
\hline $\mathrm{d}_{20}=$ & 12.50 & 7.8 & 7.35 & 8.6 & 9.8 & 13.5 & 8.2 & 8.8 & 9.4 & 9.5 \\
\hline $\mathrm{d}_{30}=$ & 12.95 & 8.0 & 7.50 & 8.8 & 9.2 & 13.5 & 8.1 & 8.5 & 9.1 & 8.8 \\
\hline $\mathrm{d}_{40}=$ & 13.15 & 8.6 & 6.30 & 8.5 & 9.5 & 13.5 & 8.0 & 8.4 & 8.7 & 8.8 \\
\hline$\% \mathrm{P}$ & 0 & 0.5 & 1 & 0 & 0.5 & 1 & 0 & 0.5 & 1 & 2 \\
\hline
\end{tabular}




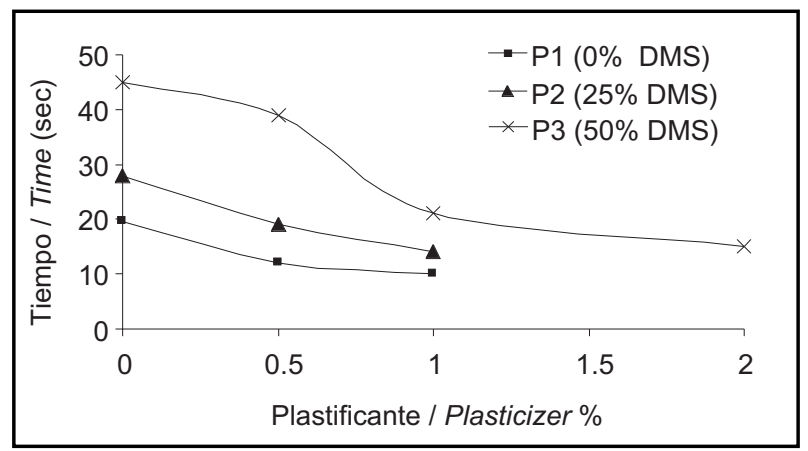

Figura 2. Tiempo de escurrimiento en pastas $\mathrm{P} 1, \mathrm{P} 2 \mathrm{Y} P 3 \operatorname{con} \mathrm{A} / \mathrm{C}=0,5$. Figure 2. Flow time in pastes $P 1, P 2 A N D P 3$ with $W / C=0.5$.

Minislump

Se llevaron a cabo ensayos de minislump en las pastas con el fin de analizar el posible empleo de DMS-0 como adición, teniendo en cuenta su fina granulación (más del 90\% pasa por un tamiz \# $250 \mu \mathrm{m}$ ). Para evaluar la cohesión, se fabricaron mezclas $(a / c=0,5)$ con un $0 \%(P 1)$, $25 \%$ (P2) y $50 \%$ (P3) de incorporación de DMS-0 por peso del cemento. Por otro lado, P1 presentó un diámetro de extensión decreciente una vez que el contenido plastificante (\%P) había aumentado. Esto se puede atribuir al efecto secundario de aceleración del plastificante según la información del fabricante. Por otra parte, la presencia de DMS-0 en $\mathrm{P} 2$ reveló un creciente diámetro de extensión en comparación con la mezcla de control cuando el contenido plastificante aumentó (Tabla 6). Finalmente, se observó una leve variación del diámetro en $\mathrm{P} 3$, lo que indica una pérdida de efectividad del plastificante debido a la gran cantidad de DMS-0 utilizada. Los estudios desarrollados por Gomes (38) revelaron que el diámetro de extensión final del minislump normalmente presenta valores más altos una vez que los contenidos de aditivo aumentan y se incorporan pequeños contenidos de filler a las mezclas. Aunque el DMS-0 utilizado en este estudio presenta características minerales que se asemejan más a las de las arenas que a las de los fillers, la incorporación de un $25 \%$ de DMS-0 significó cierta mejora de la cohesión de las mezclas y no se observó segregación alguna. Sin embargo, ninguna de las mezclas alcanzó los valores fijados como objetivo según Aïtcin (36).

\subsubsection{Morteros}

Tal y como muestra la Figura 3, se observó un despreciable aumento de la temperatura en los morteros, lo que confirma el comportamiento inercial del DMS-0 ya estudiado en las pastas. Los estudios realizados por Newman (11) con arena de dragado marino en cemento revelaron que el efecto de la sal o del contenido de cloruro actúa como un ligero acelerador cuando está presente en pequeñas cantidades (de 0,5 a 1,0\%). Tanto la
Mini slump

Mini slump tests were carried out on pastes with the aim of analyzing the possible use of DMS-0 as addition, considering its fine grading (more than $90 \%$ passes through a \# $250 \mu \mathrm{m}$ sieve). In order to evaluate cohesion, mixes $(W / c=0.5)$ with $0 \%(P 1), 25 \%(P 2)$ and $50 \%$ (P3) of DMS-0 incorporation by cement weight were fabricated. On the one hand, $P 1$ revealed a decreasing spread diameter once the plasticizer content $(\% P)$ had risen. This can be attributed to the secondary accelerating effect of the plasticizer according to the information from the manufacturer. On the other hand, the presence of DMS-0 in $P 2$ revealed an increasing spread diameter in comparison to the control mix when plasticizer content rose (Table 6). Finally, a slight diameter variation was observed in $\mathrm{P3}$, thus indicating a loss of plasticizer effectiveness due to the high amount of DMS-0 considered. Studies carried out by Gomes (38) revealed that the final spread diameter of mini slump usually presents higher values once additive contents rise and small filler contents are incorporated into the mixes. Although the DMS-0 used in this study presents mineral characteristics more similar to sands than to fillers, the incorporation of $25 \%$ of DMS-0 meant some improvement in the cohesion of the mixes, and no segregation was observed. However, none of the mixes achieved the target values according to Aitcin (36).

\subsubsection{Mortars}

As shown in Figure 3, a negligible increase of the temperature was observed on mortars, thus confirming the inertial behavior of the DMS-0 already studied in pastes. Studies performed by Newman (11) with dredged marine sand in concrete revealed that the effect of salt or chloride content acts as a mild accelerator when present in small quantities (0.5 to $1.0 \%)$. Both the rate of heat evolution and the rate of strength gain will 


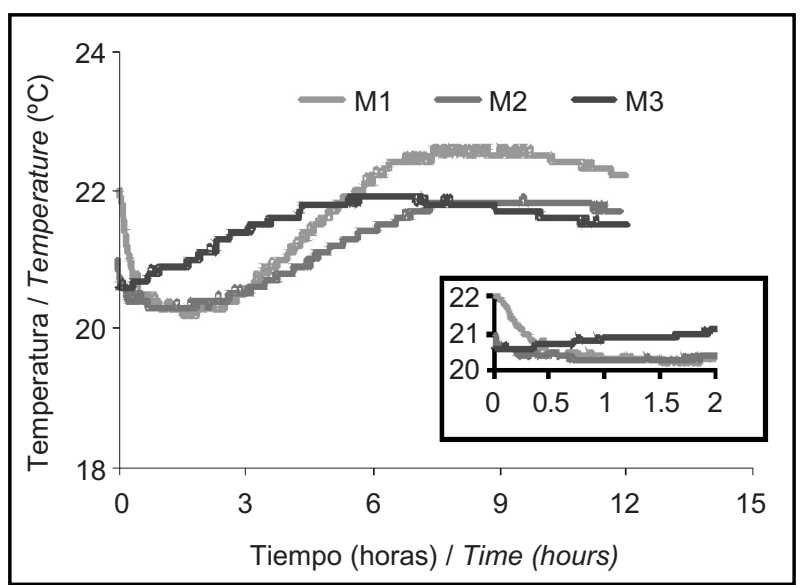

Figura 3. Evolución de la temperatura en morteros en las 12 primeras horas. Figure 3. Temperature evolution in mortars in the first 12 hours.

tasa de evolución del calor como la tasa de obtención de resistencia se acelerarán a edades tempranas, pero no a un nivel significativo. Shacklock (12) analizó el efecto del cloruro en hormigones con respecto al movimiento térmico. Según este autor, la inclusión de cloruros tiende a acelerar la evolución del calor durante la hidratación temprana y, en consecuencia, hay razones para pensar que el movimiento térmico en una estructura podría aumentar, particularmente con un tiempo caluroso. La posible magnitud de este efecto es muy difícil de evaluar, ya que están involucradas tantas variables, pero se cree que son de esperar valores desde $2^{\circ} \mathrm{C}$ hasta $3^{\circ} \mathrm{C}$.

Las mezclas de mortero M1, M2 y M3, fabricadas con un 0\%, 25\% y 50\% de DMS-0 en sustitución de NS1 0/2 mm, obtuvieron $9 \mathrm{MPa}, 7,8 \mathrm{MPa}$ y $7 \mathrm{MPa}$ de flexo-tracción, respectivamente, a la edad de 28 días.

En lo que se refiere a la resistencia a compresión, se observó un respectivo descenso del $18 \%$ y $46 \%$ en M2 y M3 con respecto a la mezcla de control M1 tras 7 días de curado. Los valores de M1, M2 y M3 fueron $41 \mathrm{MPa}$, $34 \mathrm{MPa}$ y $22 \mathrm{MPa}$ a la edad de 7 días. Tras 28 días de curado, la mezcla de mortero M2 sobrepasó en un 3\% la resistencia a compresión de la mezcla de control M1. Los respectivos valores de $\mathrm{M} 1, \mathrm{M} 2$ y $\mathrm{M} 3$ fueron $50 \mathrm{MPa}$, $52 \mathrm{MPa}$ y $37 \mathrm{MPa}$ a la edad de 28 días.

En este caso, la tasa de evolución de la resistencia a compresión puede estar relacionada con una mejor compactación del esqueleto granular de los áridos, probablemente mejorada por el DMS, lo que indica su aplicabilidad como corrector granular debido a su granulación más fina. Además, la reducción de la porosidad a causa de la hidratación del cemento contribuye a la resistencia a compresión. A los 28 días de curado, cuando la proporción de sustitución de DMS-0 aumentó del 25\% al 50\%, tuvo lugar en el mortero M3 una reducción del 34\% de la resistencia a compresión con respecto al mortero M2. be accelerated at early ages, but not in a significant amount. Shacklock (12) analyzed the effect of chloride in concretes with regard to the thermal movement. According to him, the inclusion of chlorides tends to accelerate heat evolution during early hydration and, consequently, there is reason to think that the thermal movement in a structure could be increased, particularly in hot weather. The possible magnitude of this effect is very difficult to assess, as so many variables are involved, but values from $2^{\circ} \mathrm{C}$ to $3^{\circ} \mathrm{C}$ are believed to be expected.

Mortar mixes M1, M2 and M3, fabricated with 0\%, 25\% and $50 \%$ of DMS-O in substitution of NS1 0/2 mm, obtained $9 \mathrm{MPa}, 7.8 \mathrm{MPa}$ and $7 \mathrm{MPa}$ of flexural strength, respectively, at the age of 28 days.

As far as compressive strength is concerned, a respective decrease of $18 \%$ and $46 \%$ was observed in M2 and M3 with regard to the control mix $M 1$ after 7 days of curing. The values for M1, M2 and M3 were $41 \mathrm{MPa}, 34 \mathrm{MPa}$ and $22 \mathrm{MPa}$ at the age of 7 days. After 28 days of curing, mortar mix M2 exceeded in a $3 \%$ the compressive strength of the control mix M1. Respective values for M1, M2 and M3 were $50 \mathrm{MPa}, 52 \mathrm{MPa}$ and $37 \mathrm{MPa}$ at the age of 28 days.

In this case, the rate of compressive strength evolution can be related to a better compaction of the granular skeleton of the aggregates, probably enhanced by DMS, thus indicating its applicability as a granular corrector due to its thinner grading. In addition, the reduction of the porosity due to cement hydration contributes to the compressive strength. At 28 days of curing, when the DMS-0 substitution ratio rose from $25 \%$ to $50 \%$, a reduction of $34 \%$ of the compressive strength occurred in the M3 mortar with regard to M2 mortar. This can probably be attributed to the lack of workability 
Probablemente esto puede ser atribuido a la falta de trabajabilidad mostrada por el mortero M3 y, por lo tanto, también a la falta de una compactación adecuada. Esto lo puede justificar la cantidad más alta de partículas finas que consecuentemente implica la superficie específica y demanda de agua más altas (40). Newman (11) analizó el efecto de la granulación de los áridos marinos en la trabajabilidad de hormigones frescos. Según Newman, este depende primariamente de la fracción arenosa y su uniformidad. El autor enfatiza que la trabajabilidad resultante depende de si la arena es procesada o mezclada con materiales terrestres y también del grado de drenaje realizado.

\subsection{Fase 2}

\subsubsection{Morteros}

En el caso de morteros fabricados con DMS (tipo B y C) del puerto de Barcelona y arena NS2 0/5 mm, su flexotracción a la edad de 28 días presentó un leve incremento en todas las proporciones de sustitución consideradas, en comparación con la mezcla de control REF (ver Tabla 7). Los morteros fabricados con un $15 \%$ de sustitución de NS2 0/5 mm por DMS-B y DMS-C presentaron un incremento de flexo-tracción del 18\%. En la Tabla 7 se resumen los resultados obtenidos en el ensayo para la flexo-tracción de los morteros.

Los morteros producidos con DMS-A, DMS-B y DMS-C en sustitución de arena natural NS2 0/5 mm en un $5 \%$, $15 \%$ y $25 \%$ presentaron una mejora de la resistencia a compresión con respecto a los resultados obtenidos por la mezcla de control REF (ver Tabla 8), excepto en el caso de las mezclas fabricadas con un $25 \%$ de DMS-A a los 28 días. En todos los morteros (excepto en el de $25 \%$ de DMS-B) se observó una ligera disminución de la resistencia a compresión cuando la proporción de sustitución alcanzó el $25 \%$, lo cual indica que un $25 \%$ de DMS podría ser la proporción de sustitución óptima o límite para DMS. No obstante, según Agostini et al (41), la adición de un $33 \%$ de áridos de sedimento tratado (TSA) a presented by the M3 mortar and, therefore, to the lack of appropriate compaction, too. This can be justified by the highest amount of fine particles which consequently implies the highest specific surface and water demand (40). Newman (11) analyzed the effect of marine aggregate grading on the workability of fresh concretes. According to him, it depends primarily on the sandy fraction and its uniformity. The author emphasizes that the resulting workability depends on whether the sand is processed or blended with land-based material and also on the degree of drainage which occurs.

\subsection{Stage 2}

\subsubsection{Mortars}

In the case of mortars fabricated with DMS (type B\&C) from the Port of Barcelona and NS2 0/5 mm sand, their flexural strength at the age of 28 days revealed a slight increase in all the substitution ratios considered, in comparison to the control mix REF (see Table 7). The mortars made with $15 \%$ of $N S 20 / 5 \mathrm{~mm}$ replacement by $D M S-B$ and $D M S-C$ revealed an increase in flexural strength of $18 \%$. Table 7 summarizes the test results obtained for flexural strength in mortars.

The mortars made with DMS- $A$, DMS- $B$ and DMS- $C$ in substitution of raw sand NS2 0/5 mm in 5\%, 15\% and $25 \%$ revealed an improvement in compressive strength with regard to the results obtained by the control mix REF (see Table 8), except for mixes made with $25 \%$ of DMS-A at 28 days. A slight decrease in compressive strength was observed in all mortars (except for $25 \%$ of $D M S-B$ ) when the substitution ratio reached $25 \%$, thus indicating that a $25 \%$ of DMS could be the optimum or limit substitution ratio for DMS. However, according to Agostini et al (41), the addition of a $33 \%$ of treated sediment aggregates (TSA) to cement-based materials achieved an increase of $20 \%$ in compressive strength.

Tabla 7 / Table 7

Resistencia a la flexo-tracción en morteros.

Flexural strength on mortars.

\begin{tabular}{|c|c|c|c|c|c|}
\hline \multicolumn{6}{|c|}{ Resistencia a flexo-tracción en morteros (MPa) / Flexural strength on mortars (MPa) } \\
\hline & DMS & REF (0\%) & DMS (5\%) & DMS (15\%) & DMS (25\%) \\
\hline \multirow{3}{*}{ 7 días / days } & DMS-A & 6.39 & 7.10 & 6.28 & 5.70 \\
\cline { 2 - 6 } & DMS-B & 6.39 & 6.92 & 6.8 & 6.49 \\
\cline { 2 - 6 } & DMS-C & 6.39 & 6.43 & 6.7 & 6.46 \\
\hline \multirow{3}{*}{28 días / days } & DMS-A & 6.63 & 6.52 & 6.56 & 6.16 \\
\cline { 2 - 6 } & DMS-B & 6.63 & 6.91 & 7.81 & 6.78 \\
\cline { 2 - 6 } & DMS-C & 6.63 & 6.64 & 7.83 & 7.66 \\
\hline
\end{tabular}

* DMS-A, DMS-B y DMS-C del Puerto de Barcelona se refieren a la sustitución de la arena NS2 0/5 mm. / DMS-A, DMS-B and DMS-C from the Port of Barcelona refer to $N S 2$ 0/5 $\mathrm{mm}$ replacement. 
materiales con base de cemento alcanzó un aumento de resistencia a compresión del $20 \%$. El incremento más elevado (7\%) de resistencia a compresión observado en este trabajo ocurrió cuando el $25 \%$ de NS2 fue reemplazado por DMS-B. La Tabla 8 ilustra los resultados del ensayo de compresión obtenidos con las mezclas estudiadas.
The highest increase (7\%) in compressive strength observed in this work occurred when $25 \%$ of NS2 was replaced by DMS-B. Table 8 illustrates the compressive test results obtained in the mixes studied.

Tabla 8 / Table 8

Resistencia a compresión en morteros.

Compressive strength on mortars.

\begin{tabular}{|l|c|c|c|c|c|}
\hline \multicolumn{6}{|c|}{ Resistencia a flexo-tracción en morteros (MPa) / Flexural strength on mortars (MPa) } \\
\hline & DMS & REF (0\%) & DMS (5\%) & DMS (15\%) & DMS (25\%) \\
\hline \multirow{3}{*}{ 7 días / days } & DMS-A & 29.27 & 34.35 & 34.31 & 29.98 \\
\cline { 2 - 6 } & DMS-B & 29.27 & 33.60 & 32.18 & 32.33 \\
\cline { 2 - 6 } & DMS-C & 29.27 & 31.62 & 33.43 & 32.50 \\
\hline \multirow{3}{*}{28 días / days } & DMS-A & 37.67 & 38.11 & 39.31 & 35.84 \\
\cline { 2 - 6 } & DMS-B & 37.67 & 41.26 & 41.62 & 43.95 \\
\cline { 2 - 6 } & DMS-C & 37.67 & 38.93 & 40.63 & 39.45 \\
\hline
\end{tabular}

Las propiedades en estado endurecido de los morteros M1, M2 y M3 fabricados con DMS-0 y NS1 0/2 mm obtuvieron una resistencia a compresión más alta que la de los morteros fabricados con DMS-A, DMS-B, DMS-C y NS2 0/5 mm. La resistencia a compresión de la mezcla de control M1 fabricada con NS1 0/2 mm fue un 30\% más alta que la de la mezcla de control REF fabricada con NS2 0/5 mm a la edad de 7 días; a la edad de 28 días se observó un aumento de la resistencia a compresión del $25 \%$. Esto es atribuible a la granulación más fina de la arena natural NS1 0/2 mm con respecto a NS2 0/5 mm, lo que indica que se obtiene una mejor compactación del mortero con similares proporciones de mezcla. No se incorporó ni DMS ni aditivos en ninguna de las mezclas de control. La utilización de DMS para la sustitución de arenas naturales mejoró el empaque y las propiedades de compresión de las mezclas estudiadas probablemente debido a la distribución granulométrica y a la modificación del esqueleto granular.

En este trabajo, en lo que respecta al efecto del DMS en la mejora de la resistencia a compresión, se observó que su principal influencia en los morteros está relacionada con la distribución del tamaño de las partículas, y no con el contenido de cloruro (media del 0,1\% excepto en DMS-A, como muestra la Tabla 4).

\section{CONCLUSIONES}

En base a los resultados obtenidos con este estudio, se pueden sacar las siguientes conclusiones en relación a las características de la arena de dragado marino (DMS) y su uso para la producción de pastas y morteros.
The hardened properties of the mortars M1, M2 and M3 fabricated with DMS-O and NS1 0/2 mm obtained a compressive strength higher than that of mortars fabricated with DMS-A, DMS-B, DMS-C and NS2 0/5 mm. The compressive strength of the control mix M1 made with NS1 0/2 mm was 30\% higher than the control mix REF made with NS2 $0 / 5 \mathrm{~mm}$ at the age of 7 days; at the age of 28 days an increase of $25 \%$ was observed in the compressive strength. This can be attributed to the finer grade of the raw sand NS1 0/2 $\mathrm{mm}$ with regard to NS2 $0 / 5 \mathrm{~mm}$, thus revealing a better mortar compaction obtained with similar mix proportions. No DMS or additive was incorporated into any of the control mixes. The use of DMS for the replacement of raw sands improved the packing and the compressive properties of the mixes studied probably due to the grading distribution and the modification of the granular skeleton.

In this work, as regards the effect of DMS on the enhancement of compressive strength, it was observed that its main influence on mortars is related to the particle size distribution rather than to the chloride content (average of $0.1 \%$ except for DMS-A, as shown in Table 4).

\section{CONCLUSIONS}

Regarding the characteristics of dredged marine sand (DMS) and its use on paste and mortars production, the following conclusions can be drawn on the basis of the results from this study. 
Características de la arena de dragado marino (DMS):

- La arena de dragado marino estudiada presentaba características mineralógicas y físicas similares a las de las arenas de origen terrestre.

- Se deben determinar exhaustivamente los contenidos de componentes químicos (cuando se observen contenidos de cloruro o sulfato) debido a su influencia en la durabilidad de los materiales cementicios.

- El contenido de cloruro soluble del DMS-A carecía de homogeneidad porque las probetas procedían de ubicaciones sometidas a condiciones de evaporación más severas.

Propiedades de las pastas en estado fresco:

- Las pastas mostraron una pérdida de fluidez cuando aumentó el nivel de DMS. La utilización de porcentajes más altos de materiales DMS exigía un mayor contenido de agua para alcanzar la misma consistencia normal observada en la pasta de control. Con una proporción $\mathrm{a} / \mathrm{c}=0,50$ constante y un $1 \%$ de contenido plastificante, se hallaron tiempos de flujo más bajos (similares a los de la mezcla de control) en las mezclas con un $25 \%$ de DMS como adición por peso del cemento.

- La incorporación de un 25\% de DMS significó cierta mejora en la cohesión de las mezclas (con respecto a la mezcla de control) y no se observó segregación.

- Se ha puesto de manifiesto que el cloruro no tiene ninguna influencia sobre el comportamiento de las pastas en lo que respecta a la trabajabilidad.

Propiedades de los morteros en estado endurecido:

- La resistencia a compresión de los morteros fabricados con un $25 \%$ de DMS-0 en sustitución de arena natural (fracción $0 / 2 \mathrm{~mm}$ ) experimentó un considerable incremento de los 7 a los 28 días. Por otro lado, en las mezclas con un $50 \%$ de proporción de sustitución, la resistencia a compresión no alcanzó los resultados de la mezcla de control.

- En morteros fabricados con sustitución gradual de la arena natural $0 / 5 \mathrm{~mm}$ por DMS se observó una variación similar de los 7 a los 28 días con respecto a la mejora de la resistencia de compresión de la mezcla de control.

- En todos los morteros fabricados con un $25 \%$ de DMS-A, DMS-B y DMS-C, se observó una ligera disminución de la resistencia a compresión con respecto a los morteros fabricados con un menor porcentaje de DMS. Sin embargo, este mayor porcentaje obtuvo también una mayor resistencia a compresión si se compara con la mezcla de control, lo que indica que esta es una proporción de sustitución por DMS óptima o límite.
Characteristics of dredged marine sand (DMS):

- The dredged marine sand studied showed mineralogical and physical characteristics similar to those of land-based sands.

- The chemical component contents must be determined exhaustively (when chloride or sulfate contents are observed) due to their influence on the durability of cementitious materials.

- The soluble chloride content of the DMS-A lacked homogeneity because the samples originated from location sources subjected to harsher evaporation conditions.

Fresh properties on pastes:

- Pastes showed loss of fluidity when the DMS content rose. The use of higher percentages of DMS materials required higher water content in order to obtain the same normal consistency observed in the control paste. For constant $w / c=0.50$ and $1 \%$ of plasticizer content, lower flow times (similar to those of the control mix) were found in mixes with $25 \%$ of DMS as addition by cement weight.

- The incorporation of $25 \%$ of DMS indicated a certain improvement in the cohesion of the mixes (with regard to the control mix) and no segregation was observed.

- It was revealed that chloride does not have an influence on the behavior of the pastes as regards workability.

\section{Hardened properties in mortars:}

- $\quad$ The compressive strength of the mortars made with $25 \%$ of DMS-0 in substitution of raw sand (fraction $0 / 2 \mathrm{~mm}$ ) showed a considerable increase from 7 to 28 days. On the other hand, for mixes with a $50 \%$ substitution ratio, compressive strength did not reach the control mix results.

- For mortars made with gradual substitution of raw sand $0 / 5 \mathrm{~mm}$ for $D M S$, a similar variation was observed from 7 to 28 days with regard to the enhancement of the compressive strength of the control mix.

- In all the mortars made with a $25 \%$ of DMS-A, $D M S-B$ and DMS-C, a slight decrease in compressive strength was observed with regard to mortars made with a lower percentage of DMS. However, this higher percentage obtained also a higher compressive strength if compared to the control mix, thus indicating it as an optimum or limit substitution ratio for DMS. 
- El uso de DMS para reemplazar arenas naturales con una proporción óptima de sustitución del $25 \%$ mejoró el empaque y las propiedades de compresión de las mezclas estudiadas, probablemente debido a la distribución granulométrica y a la modificación del esqueleto granular.

- El efecto del DMS en la mejora de la resistencia a compresión hizo evidente que su principal influencia está relacionada con la distribución del tamaño de las partículas en vez de con el contenido de cloruro.

- Se están desarrollando más investigaciones sobre el DMS como material para el hormigón, con el objetivo de validar su comportamiento positivo como corrector granular de finos para pavimentos portuarios de hormigón. El exceso de contenido de cloruro hallado limita el uso de DMS para hormigón en masa sin armadura, para evitar la corrosión.

\section{AGRADECIMIENTOS}

Los autores desean expresar su agradecimiento al laboratorio del Instituto de Ciencia y Tecnología del Hormigón así como al Departamento de Química de la Universidad Politécnica de Valencia (UPV).
- The use of DMS for the replacement of raw sands with an optimum substitution ratio of $25 \%$ improved the packing and compressive properties of the mixes studied, probably due to the grading distribution and the modification of the granular skeleton.

- The effect of DMS on the compressive strength enhancement revealed that its main influence is related to the particle size distribution rather than to the chloride content.

- Further research on DMS as concrete material is being developed in order to validate its positive behavior as a fine granular corrector for harbor concrete pavement. The exceeding chloride content found restricts the use of DMS for mass concrete with no reinforcement, in order to avoid corrosion.

\section{ACKNOWLEDGEMENTS}

The authors would like to thank the laboratory of the Institute of Concrete Science and Technology as well as the Chemistry Department from the Polytechnic University of Valencia - UPV.

\section{BIBLIOGRAFÍA / BIBLIOGRAPHY}

(1) Dredging and port construction. August 2007(www.dpcmagazine.com).

(2) Directive 2008/56/CE European Parliament - Marine Strategy Framework Directive.

(3) Directive 2008/105/CE European Parliament - European Water Directive.

(4) Convention for the protection of the marine environment of the north-east Atlantic. OSPAR Convention, 1992.

(5) Convention for the protection of the Mediterranean Sea against pollution. Barcelona Convention, 1995

(6) Convention on the Prevention of Marine Pollution by Dumping of Wastes and Other Matter. London Convention, 1972.

(7) Convention on the Protection of the Marine Environment of the Baltic Sea Area. Helsinki Convention, 1992.

(8) http://www.puertos.es/es/estructura/index.html

(9) Chapman, G. P.: "The sea-dredged sand and gravel industry of Great Britain", Proceedings of a Symposium: Sea-dredged aggregates for concrete. Buckinghamshire (1968).

(10) Roeder, A. R.: "Some technical data on sea-dredged aggregates", Proceedings of a Symposium: Sea-dredged aggregates for concrete. Buckinghamshire (1968).

(11) Newman, K.: "Aspects of workability, strength, shrinkage and creep", Proceedings of a Symposium: Sea-dredged aggregates for concrete. Buckinghamshire (1968).

(12) Shacklock, B. W.: "Durability of concrete made with sea-dredged aggregate", Proceedings of a Symposium: Sea-dredged aggregates for concrete. Buckinghamshire (1968).

(13) Dias, W. P. S., Seneviratne, G. A. P. S. N., Nanayakkara, S. M. A.: "Offshore sand for reinforced concrete", Construction and Building Materials, 22 (2008), pp. 1377-1384. http://dx.doi.org/10.1016/j.conbuildmat.2007.04.006

(14) Her-Yung, W.: "Durability of self-consolidating lightweight aggregate concrete using dredged silt", Construction and Building Materials, 23 (2009), pp. 2332-2337. http://dx.doi.org/10.1016/j.conbuildmat.2008.11.006

(15) Gutt, W., Collins, R. J.: "Sea-dredged aggregates in concrete", Building Research Establishment, Watford, UK, 1987.

(16) Marine aggregates in concrete, Digest 473, Building Research Establishment, Watford, UK, 2003.

(17) Colin, D.: "Valorisation de sédiments fins de dragage en technique routière". Tesis doctoral. Université de Caen, Francia, 2003.

(18) Dubois, V., Abriak, N. E., Zentar, R., Ballivy, G.: "The use of marine sediments as a pavement base material", Waste Management, 29 (2009), pp. 774-782. http://dx.doi.org/10.1016/j.wasman.2008.05.004

(19) Zentar, R., Dubois, V., Abriak, N. E.: "Mechanical behaviour and environmental impacts of a test road built with marine dredged sediments", Resources, Conservation and Recycling, 2008, vol. 52, pp. 947-954. http://dx.doi.org/10.1016/j.resconrec.2008.02.002 
(20) Kamali, S., Bernard, F., Abriak, N. E., Degrugilliers, P.: "Marine dredged sediments as new materials resource for road construction", Waste Management, 2008; vol. 28, pp. 919-928. http://dx.doi.org/10.1016/j.wasman.2007.03.027

(21) Levacher, D., Sánchez, M., Duan, Z., Le Guern, C.: "Propriétés physiques et hydrauliques de sédimentsmarins en vue de réutilisation en remblais", Xèmes Journéess Nationales Génie Côtier. Sophia, Antipolis, 2008.

(22) Levacher, D., Colin, D., Perroni, A. C., Duan, Z., Sun, L.: "Recyclage et valorisation de sédiments fins de dragage à usage de matériauxroutiers", IXèmesJournéesNationalesGénie Civil - GénieCôtier, Brest, 2006.

(23) Rekik, B., Mohamed, B.: "Étude de la compressibilité et de la micro structure d'un sédiment de dragagetraité au lianthydraulique", IXèmesJournéesNationalesGénie Civil - GénieCôtier, Brest, 2006.

(24) Boutouil, M.: "Traitement des vases de dragage par solidification/stabilization a base de ciment et additifs". Tesis doctoral, Université du Havre, Francia, 1998.

(25) Marot, F.: "Caracterisation et traitement de sediments de dragagecontenant des polluantsmetalliques". Tesis doctoral, Université du Havre, Francia, 1997.

(26) Limeira, J., Agullo, L., Etxeberria, M.: "Dredged marine sand in concrete: An experimental section of a harbor pavement", Construction and Building Materials, 24 (2010), pp. 863-870. http://dx.doi.org/10.1016/j.conbuildmat.2009.12.011

(27) UNE-EN 1097-6: Tests for mechanical and physical properties of aggregates. Part 6: Determination of particle density and water absorption.

(28) UNE-EN 933-1: 1998 Test for geometrical properties of aggregates. Part 1: determination of particle size distribution. Sieving method.

(29) UNE-EN 932-1:1997 Test for general properties of aggregates. Part 1: methods for sampling.

(30) BCR Reference materials. Report EUR 15282 EN.

(31) CEDEX - Centre for Studies and Experimentation of Public Works. "Recommendations for the Management of Dredged Material in Spanish ports".

(32) EHE 2008 - Spanish standard of structural concrete. Chapter 6, paragraphs 28.3.1 and 30.1.

(33) ASTM C 305 Standard practice for mechanical mixing of hydraulic cement pastes and mortars of plastic consistency.

(34) EN 196-3 Methods of testing cement Part 3: determination of setting times and soundness.

(35) EN 445:2009 Grout for pre-stressing tendons - Test methods.

(36) Aïtcin, P. C.: High Performance Concrete, Modern Concrete Technology 5. E \& FN Spon. 1998.

(37) Okamura, H.: "Self-compacting high performance concrete", Concrete International, vol. 19 n० 7, 1997.

(38) Gomes, P. C. C.: "Optimization and characterization of high-strength self-compacting concrete". Doctoral thesis, UPC, Barcelona, 2002.

(39) EN 196-1:2005 Methods of testing cement - Part 1: Determination of strength.

(40) Neville, A. M.: Properties of concrete; 14th Edition. Prentice Hall. 2002.

(41) Agostini, F., Skoczylas, F., Lafhaj, Z.: "About a possible valorisation in cementicious materials of polluted sediments after treatment", Cem. Concr. Compos. 2007, 29: 270-278. http://dx.doi.org/10.1016/j.cemconcomp.2006.11.012 